\title{
Effectiveness of granular columns in containing settlement
}

1 V. Sivakumar DIC, MSc, PGCHET, PhD, FICE, CEng, DSC Reader, Queen's University Belfast, Northern Ireland

2 B. C. O'Kelly BEng, PhD, MICE, CEng, FICD, FIEI, FGS Senior Lecturer, Trinity College Dublin, Ireland

3 C. Moorhead MEng, PhD

Teaching Assistant, Queen's University Belfast, Northern Ireland
4 M. R. Madhav DSC

Professor Emeritus, JNT University; Visiting Professor, IIT Hyderabad, India

5 P. A. Mackinnon BEng, PhD, MICE, CEng

Senior Lecturer, Queen's University Belfast, Northern Ireland
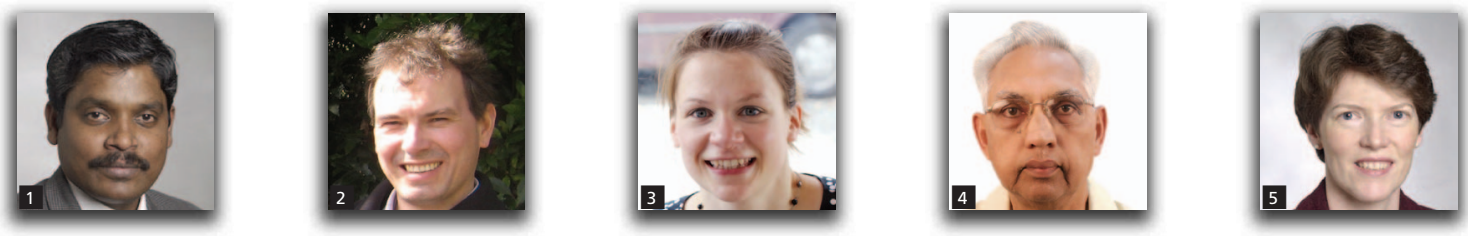

Laboratory-based research studies and full-scale evaluations of the behaviour of ground improved with granular columns are ample regarding bearing capacity, but limited in respect to the settlement response. This paper presents a laboratory model study that considers the settlement performance of isolated pad footings bearing on reinforced sand deposits under the influence of a fluctuating groundwater table. This is a particularly onerous condition for loose sand deposits in coastal areas, which may undergo significant collapse settlement over time. Loose and dense experimental sand beds were constructed, and the performance of rigid footings under a maintained load and bearing on sand incorporating different column configurations was monitored under cycling of the water table over a period of $28 \mathrm{~d}$, with one filling/empting cycle every $18 \mathrm{~h}$. It was found that settlement, while greatly reduced compared with that for unreinforced footings, was ongoing, and typically occurred at a much greater rate for loose sand than for dense sand. Also, settlement rates were slightly higher for fully penetrating than partially penetrating columns, and also for footings reinforced by a column group rather than a single column. This was attributed to the migration of sand grains into the larger column voids.

\section{Introduction}

The construction industry has developed a range of ground improvement techniques that allow sites with poor or marginal ground conditions to be developed both safely and economically. Recent years have seen increased demand globally for prime development land in major urban centres, many of which have developed along lowland coastal areas, owing to historic trading links by way of the sea. By their very nature, lowland environments are often dominated by soft or loose ground deposits, which are highly compressible or collapsible, having low strength, and may also be affected by fluctuating natural groundwater levels, particularly prevalent for loose deposits in coastal areas (Bergado et al., 1994). Similar problems can be expected for inland sand deposits such as loess, owing to periodic weather patterns (wet and dry seasons). Development on these difficult ground conditions demands careful appraisal of the most appropriate type of ground improvement method, one available option being the vibro technique, which involves the installation of granular columns (Alamgir et al., 1994; Balaam and Booker, 1981; Black et al., 2007, 2011; Charles and Watts, 1983; Hughes and Withers, 1974; Hughes et al., 1975; McCabe et al., 2009;
McKelvey et al., 2004; Pulko and Majes, 2005; Raju, 1997; Slocombe et al., 2000; Watts and Serridge, 2000; Watts et al., 2000; Wood et al., 2000).

Laboratory-based research studies and full-scale evaluations of the behaviour of ground improved with granular columns reported in the literature are ample regarding bearing capacity, but limited in respect to the settlement response, and the available information is inconclusive. For example, Black et al. (2011) reported settlement improvement factors ranging from 2 to 7 , with the higher levels attributed to some rigid boundary conditions imposed on the sample during testing. Sivakumar et al. (2010) reported lower settlement improvement factors ranging from $1 \cdot 3$ to $2 \cdot 6$. McCabe et al. (2009) also highlighted the wide range of settlement improvement factor values, with as low as 1.6 achieved under an isolated footing, such as a strip or pad foundation. The settlement improvement factors quoted above are for soft clay deposits, and the powerful vibro action will not improve the soft clay surrounding the granular columns. However, in weak granular deposits such as sand, the vibro action will also densify the surrounding soils and thereby contribute to enhanced 
performance. Nevertheless, in granular deposits foundation settlement takes place instantaneously under loading, although further settlement can also be triggered by other natural processes, such as a fluctuating water table.

The purpose of this paper is to report experimental observations collected through a laboratory-based model study on the effectiveness of granular columns in containing long-term settlement induced by a fluctuating groundwater table, for both loose and dense saturated sand deposits.

\section{Experimental programme}

The experiments were performed in a test chamber with dimensions of $1.4 \mathrm{~m} \times 0.72 \mathrm{~m}$ in plan by $0.70 \mathrm{~m}$ in depth. The inside of the chamber was coated with AquaSeal in order to prevent water leakage. Two experimental sand-bed deposits were prepared to represent loose and dense sand layers. These beds were subdivided into six bays that included different column configurations (see Figure 1 and Table 1), further details of which are presented later in the paper.

The sand beds were prepared as follows. A $5 \mathrm{~cm}$ deep gravel layer comprising $6 \mathrm{~mm}$ aggregate was first placed at the bottom of the testing chamber and overlain by a highly porous synthetic sheet. Next, slightly moist commercially available washed sand (particlesize distribution shown in Figure 2), with a natural moisture content of approximately $4 \%$, was spread into the chamber in stages, forming successive layers, each approximately $0.10 \mathrm{~m}$ in uncompacted layer thickness. For the dense sand, these layers were individually tamped using a $0.3 \mathrm{~m}$ square wooden block of $3.4 \mathrm{~kg}$ mass, which was allowed to fall 10 times at a single location from

\begin{tabular}{lcccc}
\hline $\begin{array}{l}\text { Bay } \\
\text { number }\end{array}$ & $\begin{array}{c}\text { Area } \\
\text { replacement } \\
\text { ratio: } \%\end{array}$ & $\begin{array}{c}\text { Number of } \\
\text { columns }\end{array}$ & $\begin{array}{c}\text { Loading: } \\
\text { kPa }\end{array}$ & $\begin{array}{c}\text { Column } \\
\text { depth: } m\end{array}$ \\
\hline 1 & 35 & 1 & 61 & $0 \cdot 36$ \\
2 & 35 & 1 & 61 & 0.60 \\
3 & No column & No column & 61 & - \\
4 & No column & No column & 61 & - \\
5 & 30 & 4 & 61 & 0.60 \\
6 & 35 & 1 & 93 & 0.60 \\
\hline
\end{tabular}

Bays 3 and 4: Repeat tests

\section{Table 1. Testing schedule for sand beds}

a height of $0.5 \mathrm{~m}$, and with overlapping of the tamped areas over the entire plan area of the testing chamber. The energy derived by standard Proctor compaction (i.e. $2.5 \mathrm{~kg}$ hammer free-falling 27 times through a clear distance of $0.3 \mathrm{~m}$ ) on a single area is about $196 \mathrm{~N} \mathrm{~m}$. The energy derived for the present compaction method is $172 \mathrm{~N} \mathrm{~m}$, somewhat less than standard Proctor effort. For the loose sand bed the same compaction method was applied, although the number of blows at a single location was reduced to two. Bulk densities of $\sim 1.67 \mathrm{Mg} / \mathrm{m}^{3}$ and $\sim 1.51 \mathrm{Mg} / \mathrm{m}^{3}$ were achieved for the dense and loose moist sand beds respectively. For the same water content, the bulk density of the sand achieved by standard Proctor compaction was $\sim 1.71 \mathrm{Mg} / \mathrm{m}^{3}$. The sand beds were constructed to a depth of $0.6 \mathrm{~m}$, and subsequently overlain by a $5 \mathrm{~cm}$ thick gravel layer (the gravel at the location of the footings was later removed in order for the footings to contact the top of

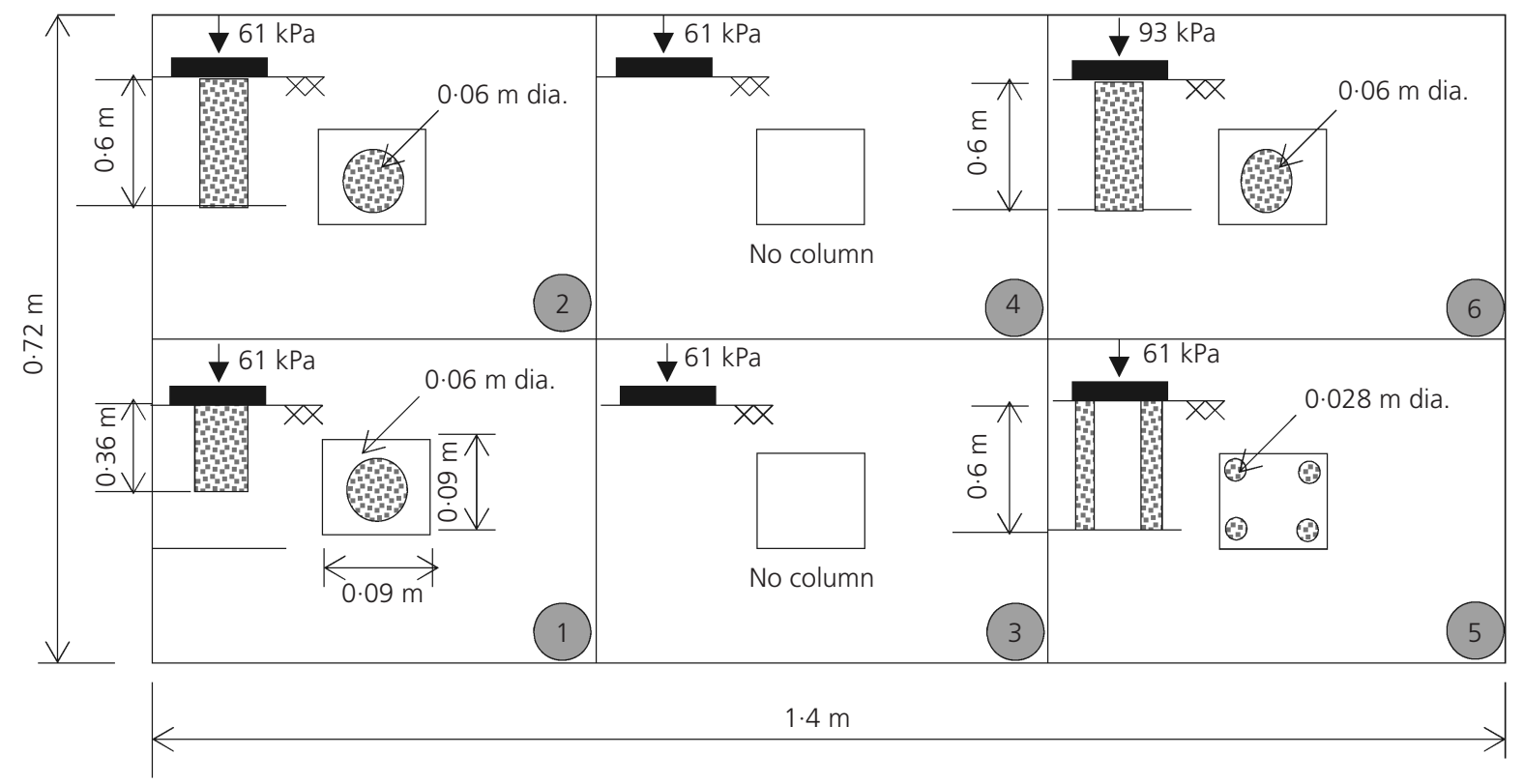

Figure 1. Footing layouts 


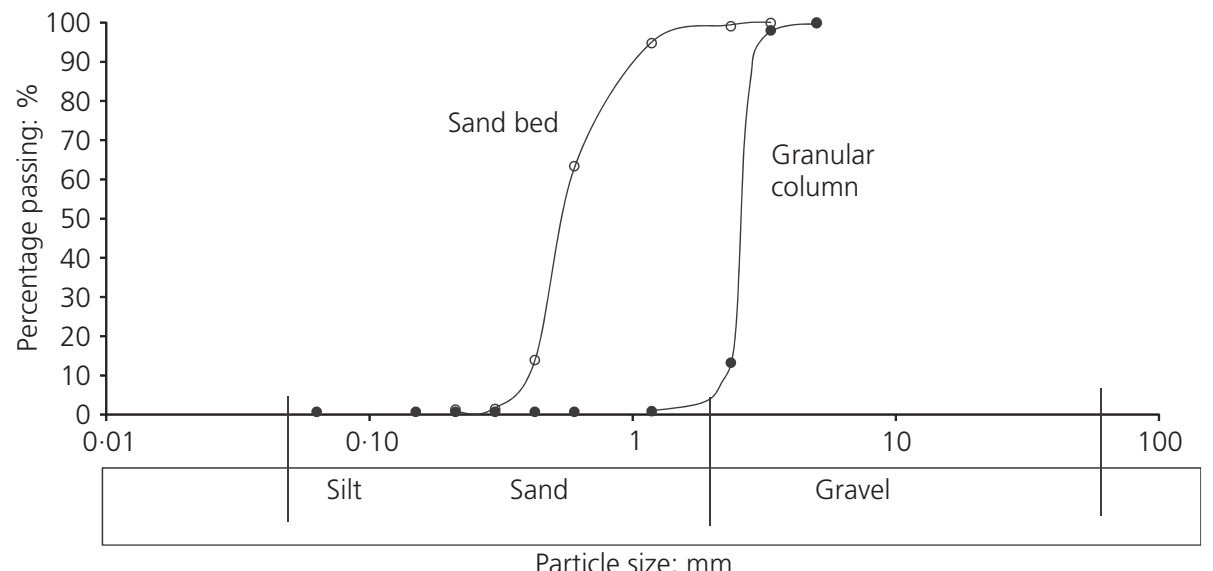

Figure 2. Particle size distribution of sand bed and granular

columns

the sand beds directly). Single and multiple column configurations (see Figure 1 and Table 1) were constructed in the compacted sand beds using uniformly graded basalt aggregate, with the particlesize distribution shown in Figure 2.

The shaft diameter for the single column configurations was $6 \mathrm{~cm}$. A smaller column diameter of $2.8 \mathrm{~cm}$ was used for the configuration with four columns located at the corners of the $9 \mathrm{~cm}$ square footing. The area replacement ratios for these arrangements were 35\% and $30 \%$ respectively, typical of values for isolated footings. However, for raft foundations, the area replacement ratio is usually around $10 \%$. The columns were installed using a displacement method whereby a poker (without vibration) with an external diameter equivalent to that of the column shaft was inserted into the sand bed, as shown in Figure 3(a). An assembly comprising a poker tube and centrally located rod and cone attachment, held together by a cotter pin, facilitated penetration of the poker into the sand bed. Upon reaching the required depth, the cone was withdrawn. The column was constructed in the sand bed in stages by compaction using a $0.5 \mathrm{~kg}$ hammer that fitted snugly inside the poker tube, and which was allowed to free-fall 10 times through a clear distance of $0.5 \mathrm{~m}$ (Figure 3(b)). The granular columns extended over the full $0.6 \mathrm{~m}$ depth of the sand beds, end-bearing at the top of the underlying gravel layer. An exception was one of the single columns (bay 2; see Figure 1), which was terminated at a depth of $0.36 \mathrm{~m}$ in the sand bed. Although the present method of column installation produced some densification of the surrounding sand for the loose sand bed, the procedure adopted in the present investigation is not directly comparable to vibro application in the field. The latter also involves horizontal vibration in order to advance the pocket into the ground, thereby causing densification of both the granular backfill and the surrounding soil (if granular in nature).

Fluctuation of the groundwater level is a common phenomenon in coastal areas, where tidal fluctuations of up to $2 \mathrm{~m}$ can be expected. The effects of this tidal variation attenuate with distance from the coastline, but are also essentially dependent on

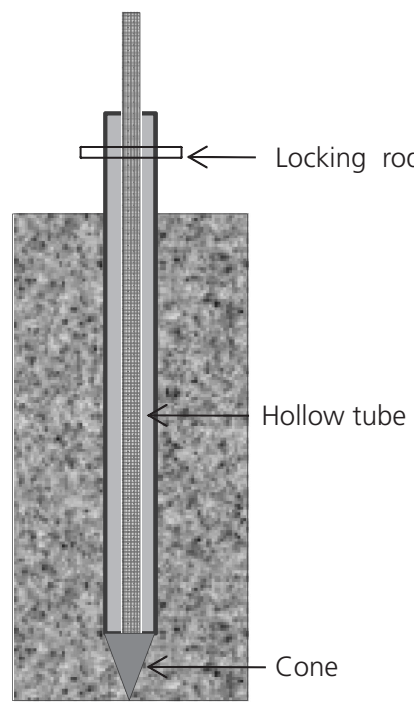

(a)

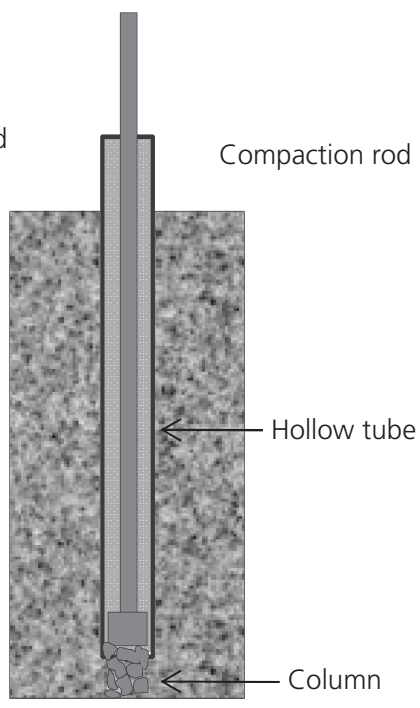

(b)
Figure 3. Column installation: (a) penetrating poker into the sand bed; (b) installation of column

the effective porosity of the deposits. Sand deposits are also found in land (e.g. loess deposits) where significant groundwater level fluctuations may also occur as a result of seasonal variation of rainfall events. Severe rainfall events may lead to a rapid raise in groundwater level, which may be reversed by even a short dry period. The intention of the present research is to assess the likely influence of such variations in groundwater level on the performance of foundations supported on weak sand deposits reinforced by granular columns.

The performance of the experimental model footings constructed in the loose and dense sand beds was studied under cyclic variation of the water table over a period of $28 \mathrm{~d}$, with one filling/empting cycle occurring every $18 \mathrm{~h}$. Considering the permeability of the 
clean sand, frequency of groundwater cycling and maximum change in water levels, it can be inferred that no significant lag occurred between the water levels in the sand bed and in the columns. Figure 4 illustrates the electronically controlled pumping arrangement used to fluctuate the water table in the testing chamber by precisely $0.55 \mathrm{~m}$ over each pumping cycle. This difference between the highest and lowest water levels was approximately equal to the full length of the columns located in bays 2, 5 and 6 . Granular columns in full-scale applications are typically $10 \mathrm{~m}$ long, although much longer columns are sometimes used. In such applications, fluctuations of $\sim 10 \mathrm{~m}$ in the groundwater level due to tidal effects are not realistic, but this situation may prevail where the groundwater table is depressed by lack of rainfall.

The pumping rate for fluctuation of the water level in the experimental sand beds was approximately $0.03 \mathrm{~m}^{3} / \mathrm{h}$. A silt trap prevented fine particles from entering the peristaltic pumping system. The settlement of the footings, and that of the sand surface remote from the footings, was measured by displacement transducers. No provisions were made to detect water pressure in the testing chamber during this process. On account of technical difficulties with the control system, pumping was not activated for the dense sand bed until four days after the deadweight loading had been placed above the footings.

Each of the rigid footings, $0.09 \mathrm{~m} \times 0.09 \mathrm{~m}$ in plan dimensions, was attached to an aluminium rod (see Figure 5) along which a $0.015 \mathrm{~m}$ diameter loading platform was secured in order to support deadweights that would apply a maintained load on the horizontal footing. The upper end of the aluminium rod had been drilled to produce a $0.022 \mathrm{~m}$ bore over a depth of $0.120 \mathrm{~m}$, which provided a sliding fit for a vertical guide bar that was secured from an independent reference frame mounted overhead, thereby preventing tilting of the footings under loading. Displacement gauges mounted on the guide bars (Figure 5(b)) monitored the footing settlement response.

Maintained loads, of either $50 \mathrm{~kg}$ or $75 \mathrm{~kg}$ mass (which produced bearing pressures of $61 \mathrm{kN} / \mathrm{m}^{2}$ and $93 \mathrm{kN} / \mathrm{m}^{2}$ respectively) were applied to the different footings (see Table 1), and the settlement response was monitored under cycling of the water table for the loose and dense sand beds over periods of $28 \mathrm{~d}$.

\section{Results, analyses and discussion}

The experimental study was specifically aimed at investigating the settlement induced by the fluctuating water table: hence reported settlements do not include the initial settlement caused directly by the application of the footing load itself. Figures 6 and 7 show the combined observations of settlement against elapsed time during the pumping test for footings supported on dense and loose sand beds, with and without granular column installations. Also included is the sand bed response sufficiently far away from the footings.

The dense sand bed was in a moist state during the initial 4-d period over which, as has already been noted, the pumping system had failed to operate owing to technical difficulties. As shown in Figure 4, settlement occurred at a very slow but steady rate, with cumulative settlement of $<0 \cdot 1 \mathrm{~mm}$ recorded by the end of this 4-d period for all set-ups. After the fourth day, the pumping system became operational, and the sand surface remote from the footings was observed to heave slightly by $\sim 0.25 \mathrm{~mm}$, but appears to have reached an equilibrium steady-state condition before the end of the 28-d pumping test. Figure 6 shows that larger footing settlements occurred for: unreinforced sand (i.e. bays 3 and 4, with the early stage of settlement highlighted in

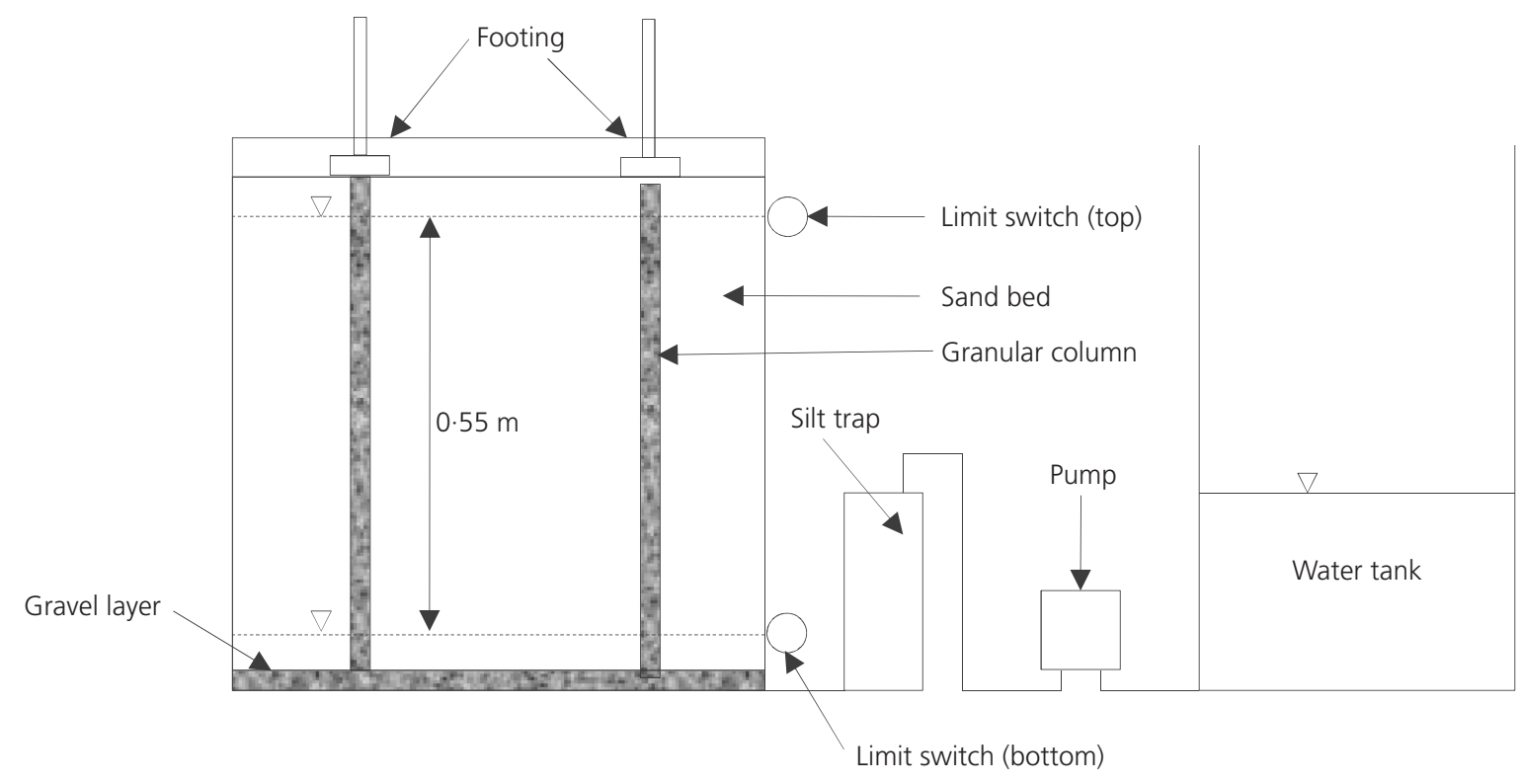

Figure 4. Sand bed pumping arrangement 


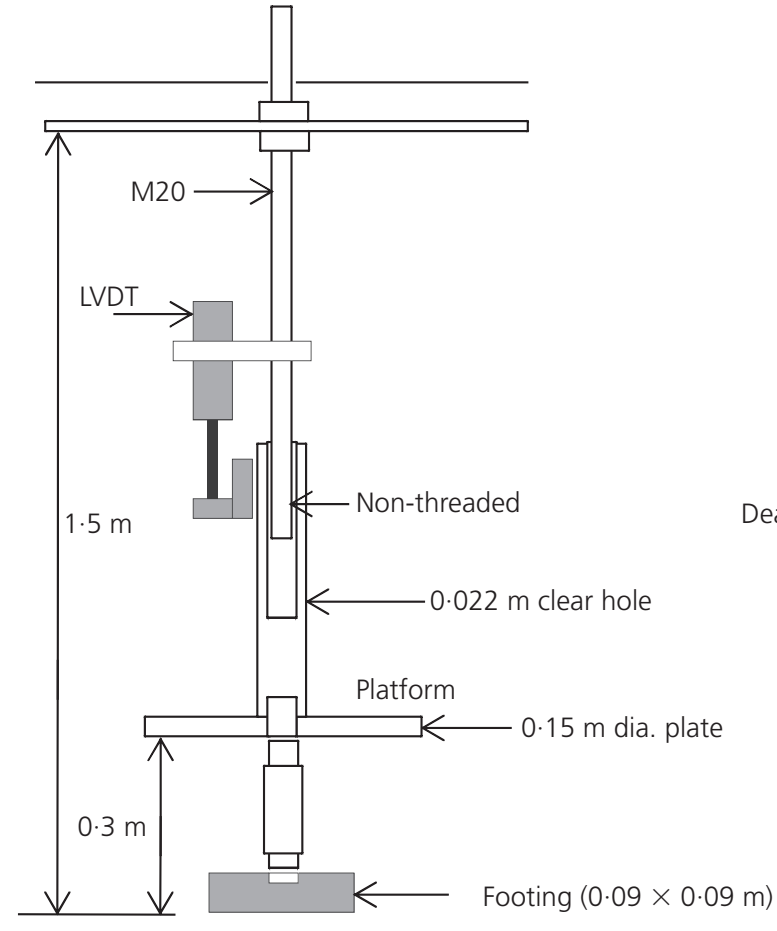

(a)

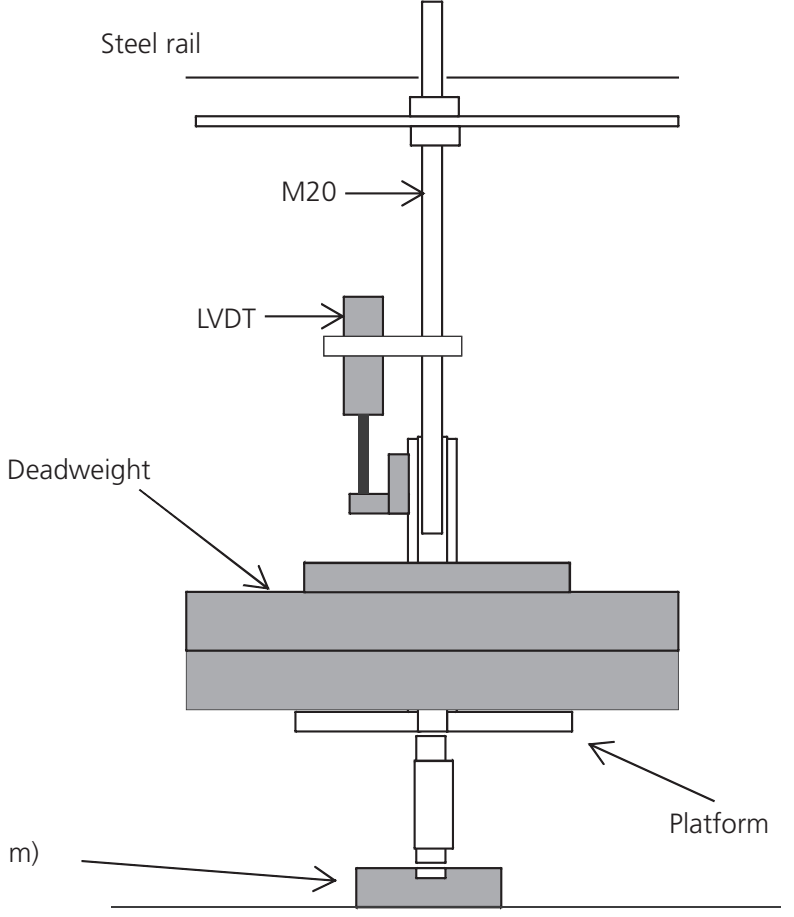

(b)

LVDT, linear variable differential transformer

Figure 5. Foundation loading: (a) footing arrangements;

(b) footing under deadweight

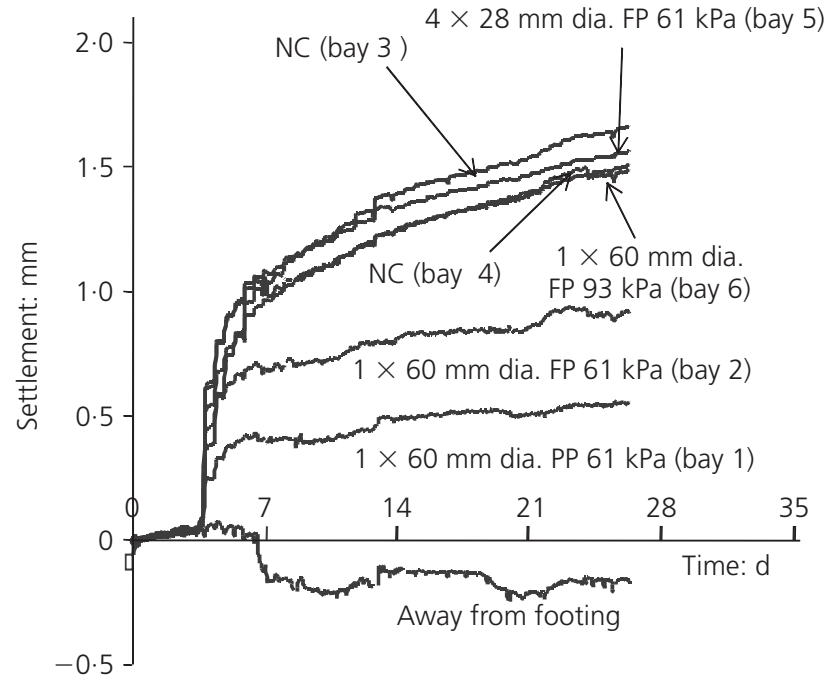

Figure 6. Settlement against time for dense sand bed (FP, fully penetrating; PP, partially penetrating)

Figure 7(b)), for sand reinforced with multiple columns (bay 5), and for footings subjected to higher bearing pressure (bay 6). Footings supported by a single column (bays 1 and 2) experienced moderate settlement. However, settlement of the footings was ongoing, albeit at a very slow rate (see Table 2), for all setups at the time of terminating the pumping. The relevant values of settlement ratio (defined as $\delta s / H$, where $\delta s$ and $H$ are recorded settlement and bed thickness respectively) in increasing order for bays $1-6$ are $8.4 \times 10^{-4}, 13.8 \times 10^{-4}, 25.8 \times 10^{-4}, 23.2 \times$ $10^{-4}, 24.5 \times 10^{-4}$ and $22.9 \times 10^{-4}$. The settlements at the end of testing are listed in Table 2 .

The loose sand bed was also in a moist state at the beginning of pumping, although, unlike the dense sand bed, the pumping cycles began immediately after the dead loading had been applied to the footings. Figure 7 shows that the sand surface sufficiently remote from the footings settled by $\sim 0.3 \mathrm{~mm}$, although it appears not to have fully reached an equilibrium steady-state condition by the end of the pumping test. Again, greater footing settlement occurred for unreinforced sand (bays 3 and 4). However, only low-to-moderate footing settlement occurred for sand reinforced by single or multiple columns (bays 1,2 and 5), with significantly lower settlement occurring for reinforced sand subjected to higher bearing pressure (bay 6). The settlement of the footings was also ongoing for all set-ups, and at a much greater rate compared with the dense sand bed (see Table 2), at the time of terminating the pumping. The relevant values of settlement ratio in increasing order for bays $1-6$ are $15.5 \times 10^{-4}, 24.6 \times 10^{-4}, 196.4 \times 10^{-4}$, $196.4 \times 10^{-4}, 44.6 \times 10^{-4}$ and $7.5 \times 10^{-4}$. The settlements at 


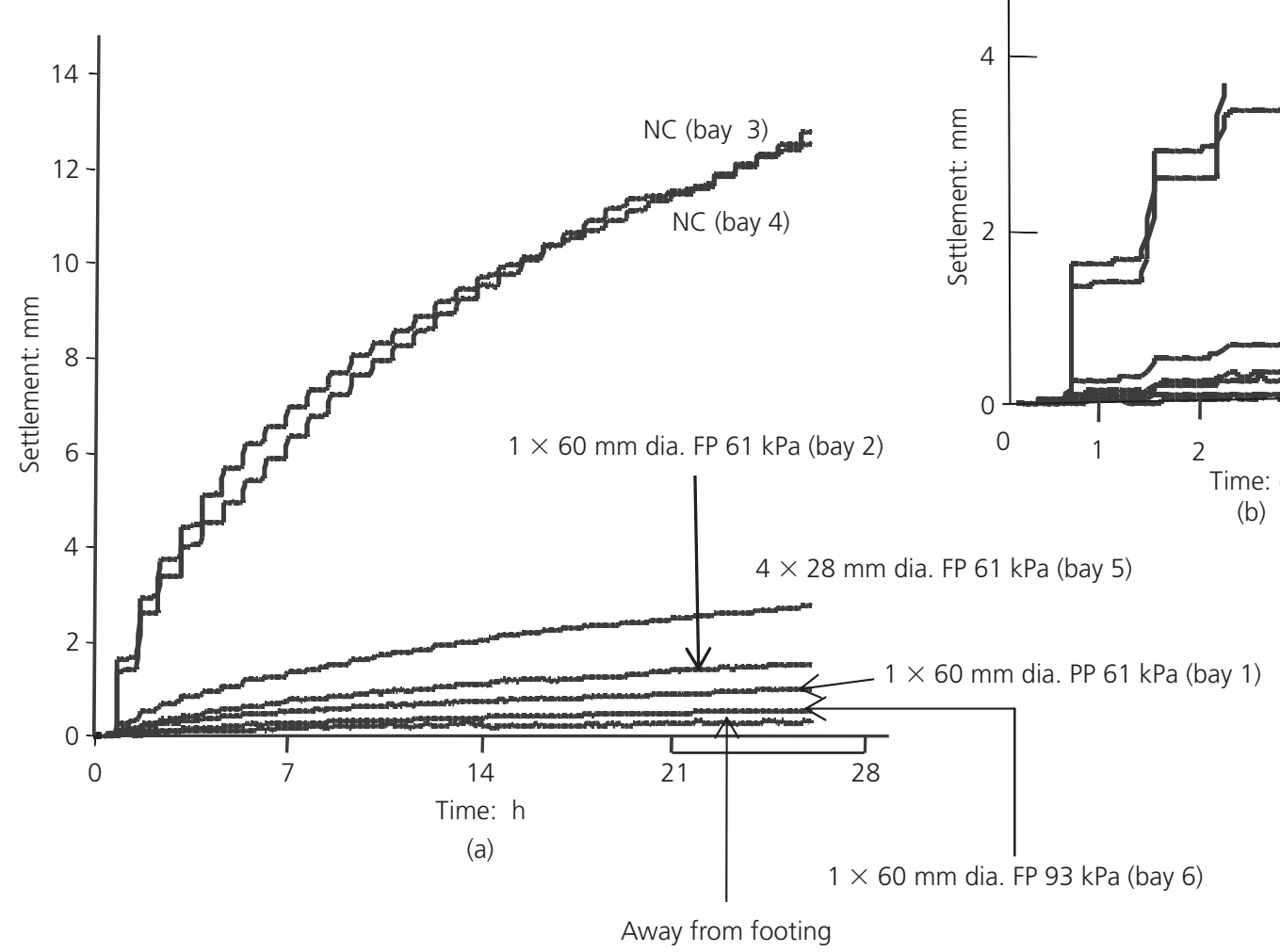

Figure 7. Settlement against time for loose sand bed (FP, fully penetrating; PP, partially penetrating): (a) period of $20 \mathrm{~d}$;

(b) period of $4 \mathrm{~d}$

Test

Bay number

Magnitude of

Rate of

Area replacement Surface area: $\mathrm{m}^{2}$ settlement: $\mathrm{mm}$ settlement: $\mathrm{mm} / \mathrm{h} \quad$ ratio, $A_{s}: \%$

Dense sand bed

Away from footing

$4 \times 28 \mathrm{~mm}$ dia. FP $61 \mathrm{kPa}$

$1 \times 60 \mathrm{~mm}$ dia. FP $61 \mathrm{kPa}$

$1 \times 60 \mathrm{~mm}$ dia. PP $61 \mathrm{kPa}$

$1 \times 60 \mathrm{~mm}$ dia. FP $93 \mathrm{kPa}$

NC

NC

Loose sand bed

Away from footing

$4 \times 28 \mathrm{~mm}$ dia. FP $61 \mathrm{kPa}$

$1 \times 60 \mathrm{~mm}$ dia. FP $61 \mathrm{kPa}$

$1 \times 60 \mathrm{~mm}$ dia. PP $61 \mathrm{kPa}$

$1 \times 60 \mathrm{~mm}$ dia. FP $93 \mathrm{kPa}$

NC

NC

$\begin{array}{lrl} & -0.25 & 0.0 \\ 5 & 1.59 & 0.0007 \\ 2 & 0.90 & 0.0004 \\ 1 & 0.55 & 0.0003 \\ 6 & 1.49 & 0.0008 \\ 3 & 1.68 & 0.0009 \\ 4 & 1.51 & 0.0008 \\ & & \\ 5 & 0.3 & 0 \\ 2 & 2.90 & 0.0023 \\ 1 & 1.60 & 0.0017 \\ 6 & 1.01 & 0.0015 \\ 3 & 0.49 & 0.0012 \\ 4 & 12.75 & 0.0107 \\ & 12.75 & 0.0107\end{array}$

0.0

$0.0007 \quad 30$

$0 \cdot 20$

$35 \quad 0.11$

$35 \quad 0.07$

$35 \quad 0.11$

NA NA

NA NA

FP, fully penetrating; PP, partially penetrating; NC, no column; NA, not applicable.

Table 2. Magnitude and rate of settlement 
the end of testing are listed in Table 2. The consistency of the sand beds produced for the model tests is evidence from the two parallel investigations performed on unreinforced loose and dense sand beds (Figures 6 and 7).

There are several factors that contributed to the observed footing settlements.

- The unreinforced sand in bays 3 and 4 is considered first. According to the effective stress concept, a rise in water table would produce heave in saturated soil. However, the sand beds in the present investigation were unsaturated at the time of placement/compaction. Hence suction, although perhaps small in magnitude, may have contributed to additional stresses at interparticle contacts caused by menisci. The removal of the menisci through wetting/inundation could lead to collapse settlement, the magnitude of which is affected by the initial density of the sand bed and stress level (Alonso et al., 1990; Sivakumar et al., 2011). Hence poorly compacted sand may undergo significant collapse settlement, even under low foundation loading, whereas dense sand may instead undergo heave under low and moderate foundation loading. The sand beds in the present investigation were taken through filling/emptying cycles, and as evident in Figures 6 and 7, the emptying process produced only small footing settlements, which occurred largely during the very early stages, becoming virtually non-existent after two or three filling/ emptying cycles. This may have been due to menisci reforming at the grain contacts upon emptying, thereby temporarily providing some additional rigidity to the sand structure. However, each time the menisci were destroyed during the filling cycle, the sand bed experienced further settlement, albeit at a reducing rate, and this is particularly evident for the loose sand bed (see Figure 7).

- Over the duration of the pumping test, the sand bed surface sufficiently remote from the footings heaved slightly by $\sim 0.25 \mathrm{~mm}$ for dense sand and settled slightly by $\sim 0.3 \mathrm{~mm}$ for loose sand. Hence it is concluded that practically all of the settlement beneath the unreinforced footings occurred over the depth of the footing stress bulb and was caused by collapse settlement as a result of repeated saturation of the sand during filling cycles.

- The footing settlement for sand bays reinforced with granular columns of different configurations is more complex. Nevertheless the granular columns were found to reduce settlement caused by the fluctuating water table for both loose and dense sand, significantly in the case of the former (refer to Table 2 and Figure 7). However, settlement continued and at different rates, depending on the column configuration and loading magnitude.

The footing load was carried by both the column head and the bearing sand directly beneath the footing. It is reasonable to assume that the initial load distribution at the start of pumping was in proportion to the rigidity of the granular column and bearing sand. The column rigidity is largely dependent on its cross-sectional area and stiffness, with the latter controlled by the relative density and physical characteristics of the gravel particles in the column, and its degree of lateral confinement. For dense sand, the dense granular column and surrounding sand could have initially carried approximately equal shares of the loading. However, a greater proportion of the loading would have initially been carried by the dense granular column for the loose sand bed. Since both loose and dense sand beds undergo settlement caused by the fluctuating water table, the load carried by the bearing sand will be gradually transferred onto the column head. The load transfer will be more significant for dense sand, since the bearing sand had initially carried approximately equal proportions of the applied loading. This increased loading on the column head will lead to densification of the gravel, as well as the occurrence of some bulging, which will lead to an enhancement of the lateral stresses in proximity to the bulging location (typically within $5 D$, where $D$ is the column diameter (Hughes et al., 1975). Understandably, the rate of load transfer from the bearing sand onto the column head reduces as the filling/ emptying cycles continue, but its intensity will be significant in the early filling/emptying cycles. The above hypothesis is supported by the fact that more pronounced settlement was found to occur during the early filling/emptying cycles for the dense sand bed reinforced by granular columns (see Figures 6 and 7).

- As has been shown in Figures 6 and 7, footings supported on sand reinforced by different configurations of granular columns resulted in distinctively different settlement performance. Sand beds incorporating a single, either partly or fully penetrating, column (bays 1 and 2) in loose sand underwent footing settlements of $1.01 \mathrm{~mm}$ and $1.60 \mathrm{~mm}$ respectively, compared with $0.55 \mathrm{~mm}$ and $0.90 \mathrm{~mm}$ respectively for dense sand. Also, settlement rates determined on the basis of the last $100 \mathrm{~h}$ of performance (see Table 2) were slightly higher for the fully penetrating column than for the partially penetrating column, which may be explained by the possibility of sand grains migrating into the larger voids of the granular column(s), with this migration of sand occurring along the entire column length. Furthermore, any sand migration into the column voids from the stress bulb for the bearing sand $(\sim 2 B)$ could lead directly to further stress transfer from the bearing sand onto the column head, thereby producing further foundation settlement. The migration of sand into the column voids for depths below the stress bulb would have a similar impact, since the progressive undermining action also has a knock-on effect at the footing/sand-bed interface.

- The rate and level of sand migration into the column voids is controlled by, among other factors, the sand state (i.e. stable for dense and unstable for loose), and also the surface area and relative density of the column or column group. Hence, in principle, a group of columns would attract more migration of sand into its void space than a single column. When pumping was terminated, footings on a single column and group of four columns in the loose sand bed had experienced 
settlements of $1.6 \mathrm{~mm}$ and $2.9 \mathrm{~mm}$ respectively (Figure 6), compared with $0.9 \mathrm{~mm}$ and $1.59 \mathrm{~mm}$ respectively for the dense sand bed (Figure 7). The settlement rate based on the last $100 \mathrm{~h}$ of data also suggests that the settlement rate for the column group was approximately twice that recorded for the single column. This agrees favourably with the surface area ratio for the single $60 \mathrm{~mm}$ diameter and four $28 \mathrm{~mm}$ diameter columns, all of which were $600 \mathrm{~mm}$ long, given that the construction technique adopted would have produced columns having similar relative density.

- It is plausible that an elevated bearing pressure would lead to a higher rate of settlement and hence larger settlement at the time of terminating the pumping. Footings with fully penetrating columns in bays 2 and 6 had been loaded to bearing pressures of $61 \mathrm{kPa}$ and $93 \mathrm{kPa}$ respectively. For dense sand, the higher bearing pressure resulted in $1.49 \mathrm{~mm}$ of settlement, compared with $0.90 \mathrm{~mm}$ under $61 \mathrm{kPa}$ bearing pressure (i.e. the amount of settlement was approximately in direct proportion to the bearing pressure). However, observations made for the loose sand bed were contradictory, with the fully penetrating column under $61 \mathrm{kPa}$ bearing pressure settling by $1.60 \mathrm{~mm}$ compared with $0.49 \mathrm{~mm}$ under $93 \mathrm{kPa}$. A plausible explanation for this behaviour was that the neck of the granular column under $93 \mathrm{kPa}$ in loose sand (and hence under lower confinement laterally) may have deformed significantly on the initial application of loading, thereby increasing the column head diameter. This is only a suggestion

The above sections have reported some interesting observations in relation to the long-term performance under cyclic variation of the groundwater table of isolated pad footings supported on sand beds reinforced by granular columns. As noted earlier, the study does not report any data for immediate settlement that occurred at the instant of applying the footing load, although immediate settlement may not be an issue in construction on granular deposits. This study has highlighted a potential settlement problem, caused by pore water pressure variation in sand deposits, that can be contained by the introduction of granular columns. However, the latter can attract additional problems, including migration of fines into the large voids of the granular column, which can also lead to settlement-related issues. Hence the settlement, while greatly reduced compared with that for unreinforced sand, still occurred at a significant rate, particularly for loose sand reinforced by a column group (see Table 2).

This study also shows that the use of longer and/or multiple columns may attract higher settlement than shorter and/or single columns; this may require full-scale field investigation. The migration of sand to the column voids may be contained by using a geosynthetic sock fitted along the column length, which also enhances the load-bearing capacity of the column by providing additional lateral confinement, particularly for loose deposits (Sivakumar et al., 2004). However, this may be difficult to incorporate in the column construction, and may also not be economical. Also, migration of sand into the columns may take place during construction of columns if robust column installation methods are employed, such as vibrating pokers.

\section{Conclusion}

The following conclusions are drawn from this laboratory-based model study on the settlement performance of isolated pad footings bearing on sands with a fluctuating water table. Granular columns reduced the amount of settlement, which was attributed largely to collapse settlement occurring during repeated saturation of the sand over the course of the filling cycles. The settlement rate was affected by the bearing pressure and relative density of the sand bed. Hence the settlement, while greatly reduced compared with that for unreinforced footings, was ongoing, and generally occurred at a much greater rate for loose sand than for dense sand, or under higher bearing pressure. However, during the early pumping cycles, the settlement rate for dense sand was significantly greater, owing to load transfer occurring between the bearing sand and the column head. This load transfer produced densification of the gravel and some column bulging, although the settlement rate quickly reduced for the dense sand, approaching an equilibrium steady-state rate significantly below that of the loose sand after only a few pumping cycles. Settlement rates were found to be slightly higher for fully penetrating than for partially penetrating columns, and also for footings reinforced by a column group compared with a single column. This was possibly caused by the migration of sand grains into the larger column voids, the rate of which was controlled by the surface area of the column or column group and the sand state.

\section{Acknowledgements}

The authors would like to thank Miss Habsliza Suhaili and $\mathrm{Mr}$ Michael Morgan for carrying out some of the testing. They would also like to thank Dr Paul Dunlop (Causeway Geotech Ltd, Ballymoney, Northern Ireland) and Mr K. V. Senthilkumaran and Mr P. J. Carey (P J Carey Contractors, UK) for unconditional financial support given to geotechnical research at Queen's University Belfast.

\section{REFERENCES}

Alamgir M, Miura N and Madhav MR (1994) Analysis of stone column reinforced ground-II: Stress transfer from stone column to soil. Reports of the Faculty of Science and Engineering, Saga University, Japan 22(1): 111-118.

Alonso EE, Gens A and Josa A (1990) A constitutive model for partially saturated soils. Géotechnique 40(3): 405-430.

Balaam NP and Booker JR (1981) Analysis of rigid rafts supported by granular piles. International Journal for Numerical and Analytical Methods in Geomechanics 5(379): 403-403.

Bergado DT, Chai JC, Alfaro MC and Balasubramanian AS (1994) Improvement Techniques of Soft Ground in Subsiding and Lowland Environment. Balkema, Rotterdam, the Netherlands. Black J, Sivakumar V and Madhav M (2007) Reinforced stone columns in weak deposits: a laboratory model study. Journal 
of Geotechnical and Geoenvironmental Engineering, ASCE 133(9): 1154-1161.

Black J, Sivakumar V and Bell A (2011) The settlement performance of stone column foundations. Géotechnique 61(11): 909-922.

Charles JA and Watts KA (1983) Compressibility of soft clay reinforced with stone columns. Proceedings of the 8 th European Conference on Soil Mechanics and Foundation Engineering, Helsinki, Finland, pp. 347-352.

Hughes JMO and Withers NJ (1974) Reinforcing of soft cohesive soils with stone columns. Ground Engineering 7(3): 42-49.

Hughes JMO, Withers NJ and Greenwood DA (1975) A field trial of the reinforcing effect of a stone column in soil. Géotechnique 25(1): 31-44.

McCabe BA, Nimmons GJ and Egan D (2009) A review of field performance of stone columns in soft soils. Geotechnical Engineering 162(6): 323-334, http://dx.doi.org/10.1680/ geng.2009.162.6.323.

McKelvey D, Sivakumar V, Bell A and Graham J (2004) Modelling vibrated stone columns in soft clay. Proceedings of the ICE Geotechnical Engineering 157(3): 137-149, http://dx.doi.org/ 10.1680/geng.2004.157.3.137.

Pulko B and Majes B (2005) Simple and accurate prediction of settlements of stone column reinforced soil. Proceedings of the 16th International Conference on Soil Mechanics and Geotechnical Engineering, Osaka, Japan, vol. 3, pp. 14011404.
Raju VR (1997) The behaviour of very soft soils improved by vibro replacement. Proceedings of the Ground Improvement Conference, London, UK, pp. 253-259.

Sivakumar V, Jeludine M and Mackinnon P (2011) The pressure distribution along columns in soft clay under consolidation and foundation loading. Géotechnique 61(7): 613-620.

Sivakumar V, McKelvy D, Graham J and Hughes D (2004) Triaxial tests on model sand columns in clay. Canadian Geotechnical Journal 41(2): 299-312.

Sivakumar V, Sivakumar R, Mackinnon PA, Boyd J and Murray M (2010) Mechanical behaviour of unsaturated kaolin (with isotropic and anisotropic stress history). Part 1: wetting and compression behaviour. Géotechnique 60(8): 581-594.

Slocombe BC, Bell AL and Baez JI (2000) The densification of granular soils using vibro methods. Géotechnique 50(6): $715-725$.

Watts KS, Johnson D, Wood LA and Saadi A (2000) An instrumented trial of vibro ground treatment supporting strip foundations in a variable fill. Géotechnique 50(6): 698-708.

Watts KS and Serridge CJ (2000) A trial of vibro bottom-feed stone column treatment in soft clay soil. In Grouting, Soil Improvement: Geosystems Including Reinforcement (Rathmayer H (ed.)). Building Information Ltd, Helsinki, Finland, pp. 549-556.

Wood DM, Hu W and Nash DFT (2000) Group effects in stone column foundations: model tests. Géotechnique 50(6): 689698.

\section{WHAT DO YOU THINK?}

To discuss this paper, please email up to 500 words to the editor at journals@ice.org.uk. Your contribution will be forwarded to the author(s) for a reply and, if considered appropriate by the editorial panel, will be published as a discussion in a future issue of the journal.

Proceedings journals rely entirely on contributions sent in by civil engineering professionals, academics and students. Papers should be 2000-5000 words long (briefing papers should be 1000-2000 words long), with adequate illustrations and references. You can submit your paper online via www.icevirtuallibrary.com/content/journals, where you will also find detailed author guidelines. 